\title{
TRANSLATION AS A COUNTERHEGEMONIC DISCURSIVE TOOL IN THE TRANSLATOR, BY LEILA ABOULELA
}

Lana Beth Ayres Franco de Araujo é mestre em Literaturas de Língua Inglesa pela UERJ

E-mail: lanaraujo@hotmail.com

\begin{abstract}
The present article aims at discussing the use of translation as a counterhegemonic discursive tool in the post-colonial scenario. In The Translator, by the Egyptian writer Leila Aboulela -, the protagonist Sammar is hired by a Scottish university to translate the Muslim universe depicted in the Qu'ran for its department of Eastern studies. Sammar, thus, uses translation as a means to bring West and East together.
\end{abstract}

\begin{abstract}
Resumo
$\mathrm{O}$ presente artigo objetiva discutir o uso da tradução como ferramenta discursiva e antihegemônica no cenário pós-colonial. Em The Translator, da escritora egípcia Leila Aboulela, a protagonista Sammar é contratada por uma universidade escocesa para traduzir para o seu departamento de estudos orientais o universo muçulmano descrito no Corão. Sammar, então, usa a tradução como um meio de aproximar Ocidente e Oriente.
\end{abstract}

Their love story is difficult (...) the problem is first one of communication - how to communicate across the borders of North/South cultural and religious difference... 1

FRIEDMAN, 2009, p.21

The present essay focuses on reflecting over translation as a counterhegemonic discursive tool in the post-colonial ${ }^{2}$ scenario, having as its backcloth the novel The Translator (1999), written by the Egyptian ${ }^{3}$ writer Leila Aboulela. It is, therefore, the aim of the current essay to see how translation can operate as "a highly manipulative activity" (BASSENTT; TRIVEDI, 1999, p.2), mainly concerning political, economic and cultural domination. However, as it will be later explained, the translation process portrayed in Aboulela's novel takes the opposite direction: it is not the dominated element who translates the dominating one in order to assimilate the former's culture; it is the dominated who translates its own culture for the dominating to comprehend it. Regarding the cultures involved in the translating activity represented in the novel, the source text in question is nothing less than the Qu'ran. Much more than a mere "original", it is the foundation of Muslim religion and commonly mistaken for the principles used as justification for all terrorist actions taken by the East against the West ${ }^{4}$. In order to analyse how this process follows a contrary direction, critical articles by Susan Bassnett, Harish Trivedi, Rosemary

\footnotetext{
${ }^{1}$ The epigraph and a few passages in the presente paper will appear in the article entitled "The Role of Translation in The Translator, by Leila Aboulela", which will be published in Seminário de Pesquisa Discente do Mestrado em Literaturas de Língua Inglesa do PPGL - UERJ 2013.

2 According to Ella Shohat (1992, p. 99), post-colonial is a "pastoral" term used euphemistically to replace the "terrorizing" neo-colonial.

3 Aboulela was born in Egypt, but grew up in Sudan and in the same city as the novel's protagonist, Khartoum.

${ }^{4}$ The concepts of West and East employed here, as the American scholar Maria Tymoczko points out, "refer to ideas and perspectives that initially originated in and became dominante in Europe, spreading from there to various locations in the world, where in some cases, such as the United States, they have also become dominant". Source: www.soas.ac.uk/literatures/satranslations/tymoczko.pdf
} 
Arroyo, Walter Benjamin, Stuart Hall, Susan Friedman, Gayatri Spivak, among others, have been used as theoretical sources. Besides the academic works previously cited, an interview with the author herself carried out by British lecturer Claire Chambers also constitutes an important reference.

The question of translation can be approached under two different perspectives: a linguistic/technical viewpoint, in which most of what is analysed is strictly related to language itself, and/or under a more encompassing one, taking into consideration concepts such as culture, history and society, which pervade and also underlie the act of translating. As Bassnett and Trivedi point out, "translation does not happen in a vacuum; it is not an isolated act, it is part of an ongoing process of intellectual transfer" (BASSNETT; TRIVEDI, 1999, p.2). So, before exploring the effects of translation in the literary scenario created by Leila Aboulela, it seems advisable to consider the concept of translation, beginning with definitions found in dictionaries.

According to the online dictionary (www.answers.com) and Longman Dictionary of Contemporary English (2003), "to translate" is respectively defined as "to render in another language; to interpret" and "to change written or spoken words into another language; to interpret". What is interesting to note is that not only the online dictionary but also the conventional one give the verb "interpret" as a synonym for "translate". Both verbs have in their morphological structure respectively the prefixes "inter", which means "between", and "trans" that stands for "through". Both particles then point to "an intermediate position", "a connection, a link between two elements" and, in the realm engendered by Leila Aboulela, translation is all about the transit and the interconnection between two completely different cultural ambiences: the economically powerful West, which for centuries has dominated and oppressed the traditional and religion-oriented East. This transit is performed by the protagonist Sammar, a Sudanese Muslim woman, hired by a Scottish university, located in the city of Aberdeen, to translate the Qu'ran, originally written in Arabic, for its department of Islamic studies. It is through Sammar's perspective, that is, through Sammar's interpretation that Rae Isles, the Western scholar she translates for, gets in touch with the rhetoric of Arabic and deepens his knowledge of the Islamic principles. In short, while translating the Muslim view of the world contained in the Qu'ran, Sammar has the opportunity to offer Rae another image of "the Other" and, thus, decenter the hegemonic West.

Although Rae, as an Eastern affairs specialist, may see the East under an angle different from the Western mainstream, it is undeniable that he has in the translation carried out by Sammar an authentic ${ }^{5}$ source of information for his academic studies. The fact that Sammar is a Muslim and an Arabic native speaker, under the eyes of the Scottish academia, confers authenticity to her translation work and authority to herself as a translator. Considering that translation involves interpretation and text elaboration, as it will be later discussed, Sammar's English version of the Qu'ran bears the relevant seal of legitimacy that it would not if the translator were white European and Christian. In Aboulela's novel, thus, Islam is not being translated by an Arabian scholar who acquired respect in the West, for instance, or even less, by a Western academician who learned Arabic in order to get a source of information not contaminated by Western biased (mis)interpretation. Islam is

\footnotetext{
${ }^{5}$ The term authentic has been written in italics for its controversial concept in cultural studies and so are the others used subsequently, which are authority and legitimacy.
} 
being translated - or rather, redecoded - by an ordinary woman who was endowed with authority to interpret the cultural realm she grew up in.

Bearing in mind that the dictionary entries quoted here is restricted to the binomial lexicon-semantics, which is by nature the purpose of dictionaries, it is interesting to regard some linguistic concepts of translation. So, a range of notions, from the traditional one, elaborated by theorists such as J.C. Catford, Eugene Nida and Alexander Fraser Tytler - at least at a primary phase of translation studies - to a newer one, based on a more comprisingly cultural view, developed since the so-called "cultural turn", which was given the way by the stance developed by American scholar James Holmes and followed by Rosemary Arrojo (2003) - who, in turn, accepts the theoretical trend proposed and developed by André Lefevere and Lawrence Venuti -, have been considered as theoretical source. According to one of the orthodox definitions of translation conceived by Scottish linguist and J.C. Catford, translation is the replacement of the textual material of one language for its equivalent in another language. So, according to Catford, translating is finding semantic equivalence ${ }^{6}$ of forms present in a given language in the other into which those forms are supposed to be translated. American theorist Eugene Nida, in his turn, built an interesting and currently worldwide known image in an attempt to explain the process of translating by means of analogy. He then compares the words that make up a sentence to wagons that compose a train. According to his analogy, each of those wagons carries a given load, that is, each word in a sentence carries a determined meaning. Between the two languages involved, then, the load of each unit, or rather, the meaning of each word often varies and the correspondence between those wagons differs likewise.

It is likely to happen that, during the translation process, the corresponding forms in the languages participants in the "game of translation" ${ }^{7}$ " are quite different. In other words, if, in the source language, it is necessary to use one word to convey a given meaning, in the target language, that same "semantic load" might need a more complex or maybe a simpler structure to be expressed. What Nida's analogy means is that, during the act of translating, the same content might assume a different form. Therefore, based on Catford and Nida's concept of translation, similarly, a translator's task would be strictly that of transporting meanings. The translator then, in the light of the canonic linguistics, is supposed to master both linguistic systems, in order to be able to transport that exact message from the source into the target language. This way, he or she is able to weave the translated text, that is, the final product of the translation process, without changing the original, the primary message produced by its author, not taking into consideration here the controversy which involves the concept of "original" in translation studies. However, that process of "semantic transference" and "structural adaptation", still in the light of the traditional linguistic perspective, cannot suffer any kind of interference on the part of its agent, the translator. In short, a translator is not allowed to lend the translated text any personal data, since any change of this sort could affect what those theorists understand as "original text", that is, the textual production elaborated by its author. Thus, it is expected

\footnotetext{
${ }^{6}$ The term equivalence was questioned by American scholar James Holmes, who proposed its replacement by the term correspondence, as informed by Paulo Henriques Britto in his work A tradução literária, included in the References.

${ }^{7}$ Brazilian professor Paulo Henriques Britto (2012, p. 28) defines as "game of translation the set of rules that come into play during the translation process. One of these rules consists of weaving a text as close to the original as possible, as if in a "centripetal process", as Britto himself names it $(2012$, p. 35). This proximity is something quite difficult to acquire regarding such different cultures.
} 
from the translator that he or she keeps detached from the message to be translated, in order to be able to preserve the original content.

On the other hand, the view of translation postulated by Lefevere and Venuti and embraced by Arrojo and Bassnett consists of the effects the translator's personal experience can produce on the translated text. In this sense, the translated text is certainly contaminated with the readings he or she performed and all the knowledge the translator has acquired as a person and as a professional. Under this perspective then, translation is undoubtedly interpretation, that is, it is the attempt to capture the author's original intentions, which can only be made by means of the translator's reading. Therefore, translation is the translator's personal understanding of the author's textual purposes. While discussing literary translation - and it is applicable to any type of translation -, based on Estonian semiotician Juri Lotma's theory, Bassnett argues that the translator is, first and foremost, a specialized reader who, while interpreting the text he is supposed to translate, must "[...] understand [the] complex set of systems existing in a dialectical relationship with other sets outside its boundaries [...]" (BASSNETT, 2014, p. 89).

Although it is known that the Qu'ran, the text which will be rendered into English in Aboulela's novel, cannot be categorized within the literary genre, it must be pointed out here that, as the Bible, the Islamic holy book is pervaded by images, metaphors and figures of speech that convey a whole world view that Sammar is supposed to redecode in English. In taking over the task of "redecoding", the translator, after interpreting, rewrites the text subjected to the translation process. Therefore, if, on the one hand, a translator's work involves interpretation in a first moment, on the other, it also includes rewriting in a second step. While rewriting the original text, the translator sprinkles in the text he or she is reweaving his or her interpretation of the original. Thus, purposely or not, the translator ends up manipulating the content of the translated text and, consequently, the understanding of its recipient. As it seems, assuming the condition of interpreter and rewriter, the translator is unlikely to keep himself or herself detached from the "original", as the canonic linguistics proposes, and nor does his or her work restrict itself to transporting meanings between two different languages. About this aspect, André Lefevere and Susan Bassnett, in the preface of Lefevere's book (2007) argue that:

[t]ranslation is certainly the rewriting of an original text. Any rewriting, regardless of its intention, reflects a certain ideology and a certain poetics and, as such, manipulates literature so that it works within a given society and in a given way. Rewriting is manipulation, carried out at the service of power and, in its positive aspect, can foster the development of a given literature and a society. Rewriting works can introduce new concepts, new genres, new artifacts and the history of translation is also that of literary innovation, of the power that moulds a culture on another one (BASSNETT; LEFEVERE, 2007, p. 11-12 - my translation).

What is important to remind here is that translation in Aboulela's novel is not at the service of European mainstream with the purpose of producing a distorted view of the Islamic philosophy. Quite the contrary, translation is being used as a means of reaching the most genuine interpretation of the Islamic culture portrayed in the Qu'ran. Sammar, as the translator referred to in the title of the novel, skillfully makes use of translation in order to drag Rae Isles into Islam. The Scottish academician turns out to be the perfect recipient of her rewritten text, as he is, for all reasons, open to grasp her message. 
Taking into consideration both concepts of the translator as a reader/interpreter and as a rewriter as well, it would be interesting to observe here what Maria Tymoczko (1999) says about this second step of a translator's work, which is the weaver of a second text, having an "original" as its starting point. While approaching post-colonial writing and literary translation, Tymoczko parallels both professionals - a writer and a translator - and attributes to the former the task of writing and the latter that of rewriting the same text. Tymockzko's classifying the writer's post-colonial cultural background as a metatext which is being rewritten during the translation process parallels the idea of translation as a palimpsest developed by Rosemary Arrojo (2003).

[A] literary translator is [...] concerned with differences not just in language (transposing word for word, mechanically), but with the same range of cultural factors that a writer must address when writing to a receiving audience composed partially or primarily of people from a different culture. The culture or tradition of a post-colonial writer acts as a metatext which is rewritten [...] in the act of literary creation. The task of the interlingual translator [- which is Sammar's case -], has much in common with the task of the post-colonial writer; where one has a text [the product of a primary creation work], [...] the other has the metatext of culture itself [which he/she is supposed to re-engender in another language]. (TYMOCZKO, 1999, p. 21).

Metaphorically, in our "workshop", the "palimpsest" becomes the text which is erased in each cultural community and in each epoch, in order to give way to another writing (or interpretation, or reading, or translation) of the "same" text. [...] What we have, what is possible for us to have, are its many readings, its many interpretations, its many palimpsests. The translation, as [a sort of] reading, is no longer an activity which protects an author's "original" meanings [but one that] assumes its condition of producer of meanings (ARROJO, 2003, p. 23-24).

Sharing Maria Tymockzko and Rosemary Arrojo's points of view, professor Klondy Lucia de Oliveira Agra, a researcher from Universidade Federal de Rondônia, in her article entitled "A integração da língua e da cultura no processo da tradução" (sem data de publicação), argues that translation, unlike the definitions found in dictionaries, is not related to significance. It is not limited to the mere association between concept and word, but rather, to the senses an individual builds from the cultural ambience that surrounds him or her. In order to give theoretical support to the connection she establishes between translation and culture, Klondy then outlines the concepts of language, culture and translation. Before doing so, however, it is important to point out here that the word language in English means not only "the system of communication by written or spoken words, which is used by the people of a particular country or area", as Longman Dictionary of Contemporary English registers, but also the various uses (written/spoken, formal/informal) of that system in a certain society. Those meanings, in Portuguese, receive the distinguishing labels lingua and linguagem ${ }^{8}$, respectively. Regarding the first concept, Klondy states that language is something of social and historical natures, determined by the specific conditions of a given society and its culture; referring to the second one, language is a symbolic code by means of which messages are sent and understood, information is decoded and classified and events are announced and interpreted. Culture, in its turn, stands

\footnotetext{
${ }^{8}$ Source: Dicionário eletrônico Houaiss da língua portuguesa 3.0 
for the set of actions which characterize a social group in a given moment: clothing, food and the way that social group eats it, customs, thoughts and beliefs. She then compares the last two concepts, arguing that both the second definition of language and culture constitute symbolic codes through which messages are transmitted and received, or rather, interpreted.

Then, while performing a translation work, the translator must take into consideration not only the decoding of words, phrases and sentences and the correspondence of meaning, but mainly, the author's senses, the context, the scenario to be translated - and it is what Aboulela's protagonist does in the novel. Therefore, when it comes to translation, the concepts of language and culture are undoubtedly complementary, as the former embodies the tool with which the second gets its formalized (written) register. In short, it is language that perpetuates culture within its country of origin and also allows it to be transmitted to other different cultures/peoples. Regarding culture, the translator plays a decisive role as it is his or her expertise that will enable cultural interconnection. In order to illustrate the close relation between language - considering both meanings - and culture, Klondy quotes Susan Bassnett's text in which she compares language and culture to a human heart and a human body in her book Translation Studies, showing that no translation work can be carried out without considering the cultural aspect that permeates and also supports both concepts of language approached here.

Language, then, is the heart within the body of culture, and it is the interaction between the two results in the continuation of life-energy. In the same way that the surgeon, operating on the heart, cannot neglect the body that surrounds it, so the translator treats the text in isolation from the culture at his peril (BASSNETT apud AGRA at www.bocc.ubi.pt).

In the 2014 edition of her book Translation Studies, Bassnett devotes its first chapter to translation central issues and three of them, which work in an intertwined mode, are particularly pertinent to the focus of this paper: language and culture, decoding and redecoding and untranslatability. While discussing the relation between language and culture, Bassnett quotes Polish linguist Edward Sapir, who asserts that "language is a guide to social reality" (SAPIR, apud BASSNETT, 2014, p. 24). Understanding that language and translation are concepts that cannot be dissociated and, as such, form a binomial, we can establish a connection between Sapir's statement and the plot in The Translator. Once working as a translator for Rae, Sammar then operates as the guide who will conduct her social - religious and cultural as well - reality towards a Western scholar. Eventually, however, by means of decoding and redecoding the Qu'ran from Arabic into English, she managed to perform the contrary movement: by means of translation, she ended up conducting Rae into her reality, as he converted into Islam at the end of the novel. When it comes to the linguistic procedures carried out during the translation activity, Bassnett (2014, p. 26) approaches Eugene Nida's model, already mentioned in the present paper, according to which the translation process would occur as follows: 
SOURCE LANGUAGE

TEXT

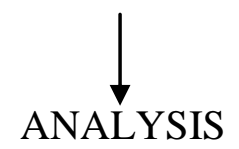

RECEPTOR LANGUAGE TRANSLATION

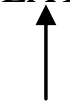

RESTRUCTURING

TRANSFER

Adapting Nida's translation model illustrated in the previous diagram to the courses taken by Sammar and Rae in The Translator, the scheme would be the following:

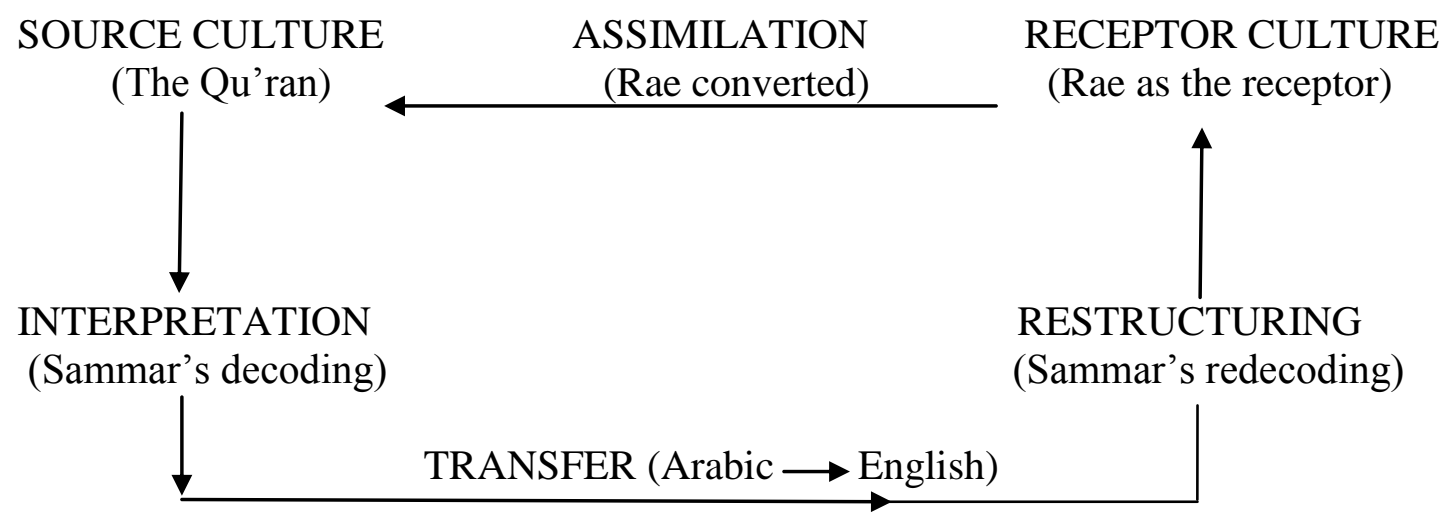

For a better understanding of the second chart, it is fundamental that we take into account the context in which Sammar's translation work develops. The protagonist in Aboulela's novel leaves Sudan and heads for Scotland to translate the Qu'ran for a Scottish scholar who specializes in Eastern culture. As previously informed, a Western academia relies on a non-Western translator's work in order to grasp the cultural markers described through the Arabic's rhetoric, without taking the risk of having it contaminated with Western misinterpretation - and, thus, mistranslation. It is not, thus, a Western scholar who learned Arabic who performed the translation which will be used as reference in the department. In order to have a reliable key to the Islamic culture ${ }^{9}$, the Scotish academia hired a translator who is Islamic and also a native Arabic speaker. Sammar's professional commitment in Scotland, therefore, involves equally linguistic (language itself) and extralinguistic (concepts textually transcribed) factors, which André Lefevere (1998, p. 75) terms as grids in his article "Composing the Other", also included in Bassnett and Trivedi's collection on post-colonial translation, already mentioned in this paper. Later, in the same essay, Lefevere approaches translation as a communicative process, the success of which depends on the predisposition of the recipient of the messages - the translated text, in this case - to surrender to that flow of (translated) information pervaded by cultural markers that must be detected. In The Translator, more than detecting the cultural markers present

\footnotetext{
${ }^{9}$ The term culture must be understood here as "the beliefs, way of life, art, and customs that are shared and accepted by people in a particular society" (Longman Dicitionary of Contemporary English, 2003, p. 382). 


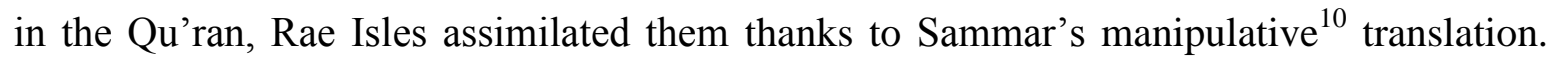
About this feature of translation, Lefevere points out:

The success of communication depends on both the writer [- or translator] and the reader [or translation consumer] of the text agreeing to play their assigned parts in connection with [the] markers [involved]. The writer [or translator] is supposed to put them in, the reader [or translation consumer] is supposed to recognize them. [...] Problems in translating are caused $[\ldots]$ by discrepancies in conceptual and textual grids as by discrepancies in languages. [...] [M] uch more than on the linguistic level, lies an argument in favour of the creativity of translators: like writers of originals, they too have to find ways of manipulating the grids in such a way that communication becomes not only possible, but interesting and attractive. (LEFEVERE, 1998, p. 76-77)

It seems legitimate to affirm that Rae's conversion to Islam is the outcome of a process that took place during his contact with Sammar. Probably, by means of her translation of the Qu'ran- along with discussions between them over the issues brought up - , the characters in question interacted in a communicative process performed during the translation activity.

Regarding untranslatability, the third issue raised by Bassnett (2014), and also a recurrent theme in translation studies, it has been historically discussed by those devoted to theorize the translation process. About the supposed "impossibility of translation", Paulo Rónai (2012) refers to the $18^{\text {th }}$ century German philosopher Johann Gottfried von Herder, who sustained that human thought is conditioned by language. This way, ideas represented by signs of a given language can only "be born in the mind of those who speak [that very] language. (RÓNAI, 2012, p. 15 - my translation) This position, taken over two hundred years before Aboulela's writing The Translator, is also shared by Sammar and Fareed, another Muslim character who also transit in the academic ambience as the protagonist does, as it will be exemplified by the excerpts shown later.

What needs to be pointed out is that, in a nutshell, the problem raised by translation studies lies in the relationship between signifier (the physical word, the phonetic mass concretely represented by a sequence of letters) and signified (the idea, the notion the signifier represents, describes) in one language and its reading, interpretation and redecoding-rewriting from the source language into the target one. However, since this three-phase act of reading, interpreting and redecoding-rewriting involves languages which represent thoroughly different cultures, it must be questioned here whether that reading/interpreting/redecoding-rewriting process is viable. This was the aspect focused on by Walter Benjamin in his critical work The Task of the Translator, written in 1923, with the intention of discussing how to translate Baudelaire's poems. Benjamin then describes translation as a mode, word registered in Longman Dictionary of Contemporary English as "a particular way or style of behaving, living or doing something". Note the presence of the adjective particular which suggests "something belonging to a specific person or group": that idea of particular then might point either to the individual who is supposed to $\mathrm{read} /$ interpret/redecode-rewrite a text or to the text itself, taking it as a source of cultural information. Benjamin then goes on stating that "... to comprehend [translation] as a mode,

\footnotetext{
${ }^{10}$ The adjetive manipulative does not have the pejorative stance registered in most dictionaries. It has much more to do with the skill in convincing through discursive manoeuvres.
} 
one must go back to the original, for that contains the law governing the translation: its translatability" (BENJAMIN, 2000, p. 4).

So, it must be questioned here whether it is possible to translate something firstly written in a given language portraying such a different cultural realm in relation to that which represents the host culture, the culture which is supposed to receive the cultural load in question. What words/phrases/expressions should be used to express an idea that does not exist in the called target language? How to make a foreign reader understand feelings, standpoints, sensations, ideas, he or she has never experienced, or whose existence he or she does not even know about. In this respect, a dialog between Sammar and Fareed, in which they discuss about the difficulty of translating the Qur'an, shows that both agree with Walter Benjamin, when it comes to whether or not some texts are "translatable".

Translations don't do justice. Much is lost (...) (Fareed in ABOULELA, 2006, p. 124)

Yes, the meanings can be translated but not reproduced. And of course the miracle of it can't be reproduced. (Sammar in ABOULELA, 2006, p. 124)

The characters talking in the passages previously quoted reinforce the concept of untranslatability, pioneered by Herder in his On Dilligence in Several Learned Langages, written in 1764 and highlighted by Walter Benjamin in the early twenties of the last century. In fact, Fareed realizes the "untranslatability" of certain texts, mainly those of religious/philosophical nature, upon which Sammar agrees when she recognizes that translation, in the light of that orthodox view, is possible, but the "miracle", the effect such a text can have in a person's soul cannot be "reproduced". However, contrary to the opinions expressed above, the translation of the Qur'an was effectively performed, as Sammar made it perfectly "translatable" by means of a successful redecoding/rewriting of the rhetoric of Arabic into English, which eventually triggered Rae's conversion to Islam.

Still on the question of untranslatability, Bassnett resorts to the two types distinguished by J.C. Catford: the one of linguistic nature and the other of cultural feature, being the latter more intricate. In Bassnett's words, "cultural untranslatability is due to the absence in the [target language] culture of a relevant situational feature for the [source language] text" (BASSNETT, 2014, p. 41 - my emphasis). Theoretically speaking, the principles postulated in Arabic in the Qu'ran would not have to Rae, regardless of his intimacy - and sympathy - with Easter affairs, the same "relevant situational feature" as it has for Muslims as Sammar and Fareed. Even acknowledging that culture is permanently subjected to an ongoing process of transformation, especially in a globalized world as this we live in, making a Western scholar grasp completely the content of such a source text, whose principles are criticized by the Western mainstream, is undoubtedly a very difficult task.

Now, if we work with the premise that translation is indeed interpretation and rewriting, we must reflect over the figure of the agent of this process. What kind of translator is Sammar? What cultural background supports her? In this respect, the three-part relation between "source language", translator and "target language" seems to be more intricate when the professional involved is someone who is deeply attached to his or her culture and, for economic reasons, is somehow forced to leave the place with which he or she has a strong sense of belonging and move out to another one, which is expected to be 
hostile. This is what is currently called post-colonial diaspora, the origins of which theorists Jana Evans Braziel, Anita Mannur and Stuart Hall define and discuss:

Once conceptualized as an exilic or nostalgic dislocation from homeland, diaspora has attained new epistemological, political, and identitarian resonances as its points of reference proliferate. The term "diaspora" has been increasingly used by anthropologists, literary [and translation] theorists, and cultural critics to describe the mass migrations and displacements of the second half of the twentieth century, particularly in reference to independence movements in formerly colonized areas, waves of refugees fleeing war-torn states and fluxes of economic migration in the post-World War II era (BRAZIEL; MANNUR, 2003, p. 2).

Poverty, underdevelopment, the lack of opportunities - the legacies of Empire everywhere may force people to migrate, bringing about the scattering - the dispersal. But each dissemination carries with it the promise of the redemptive return. This powerful interpretation of the concept of "diaspora" has become part of our newly constructed collective sense of self and deeply written in a subtext in nationalist histories (HALL, 1999, p. 3-4).

In order to outline the profile of Sammar as a translator, it seems crucial to take into account her trajectory as an individual. Sammar was born in Scotland, a child of Sudanese parents who supposedly went to Europe for economic reasons. At seven years of age, the family goes back to Sudan, being this time Sammar's first physical contact with her parents' land. Years later, already a married woman, she goes back to Scotland, where her husband - and cousin - would attend medical school and where he eventually died in a car crash. As it is revealed throughout Aboulela's novel, Sammar is what could be called here as a "child of diaspora", a sort that Stuart Hall defines as "black diaspora" (HALL, 1999, p.1), so as to distinguish it from the Jewish one, historically known and recognized. Sammar was born in this cultural in-between, being a Scotish citizen, just by chance, by geographical circumstances. When it comes to cultural identity, however, she is indeed a Sudanese individual, who must have grown up in a domestic ambience, where the Sudanese ethos probably was maintained, with all its composing elements preserved: language, religion, food. As it seems, although physically in Scotland, Sammar must have been subjected to what American anthropologist James Clifford (1997, p. 255) calls "language of diaspora". Attempting to prevent their past from being erased by an acculturation process, Sammar's family seems to have made a point to keep Islam within their house in Aberdeen. Thus, by maintaining tradition, Sammar's parents built a "home", out of which Sammar felt displaced, even mastering the English language. Sammar's diasporic experience, therefore, fostered a translator who could perfectly deal with two different language systems, but could only translate the cultural elements present in one of them, the one she identifies as her mother tongue. This closeness with Arabic and Islam, as said before, confers to Sammar's translation an important feature: legitimacy. The diasporic experience is extremely relevant when it comes to language - and consequently, to translation - as cultural identity deeply affects the positionality ${ }^{11}$ of the agent of the translating activity. And the translation process gets contours even trickier when the culture the translator is

${ }^{11}$ Positionality is a term often used in cultural studies which means an individual's point of view formed along his/her life experience.

Revista Escrita

Rua Marquês de São Vicente, 225 Gávea/RJ CEP 22451-900 Brasil

Ano 2014. Número 19. ISSN 1679-6888.

escrita@puc-rio.br 
attached to imposes stiff customs, is religion-oriented and, thus, has in relation to West the same Manichean view West has towards East. The situation described here seems to be that faced by Sammar, the protagonist created by Leila Aboulela and who provides the title to the novel. Before reflecting over Sammar as a translator, it would be useful to consider some other theoretical views which regard the act of translating not as a strictly linguistic event, but as something of cultural stance which involves philosophy, anthropology and history, to say the least, under both individual and collective perspectives. Following this direction, Indian literary critic and professor Gayatri Spivak, in the ninth chapter of her work Outside in the Teaching Machine, entitled "The Politics of Translation", gives a comprehensive definition of language, which is corroborated by Claire Chambers while quoting the novel in the article in which she reproduced the interview with the author already mentioned here:

In my view, language may be one of the many elements that allow us to make sense of things, of ourselves. I am thinking [...] of gestures, pauses, but also of chance, of subindividual force-fields of being which click into place in different situations, swerve from the straight or true line of language-and-thought. Making sense of ourselves is what produces identity (SPIVAK, 1993, p. 179).

As this summary suggests, and as the title makes clear, this is a novel all about translation: not just the literal linguistic translation that Sammar is involved in, from Arabic into English, but also cultural translation. Sammar's view of her translation work is that she is involved in "moulding Arabic into English, trying to be transparent like a pane of glass not obscuring the meaning of any word" (CHAMBERS, 2009, p. 8).

In Aboulela's novel, Sammar, in order to construct her own identity in a Western environment, swerves from the binomial language-thought and searches for extranlinguistic elements to covert the ideology described in Arabic into something corresponding in English. It is through language - and translation - that Sammar keeps both West and East connected, commuting from one to the other by "transforming the Arabic rhetoric into English" (ABOULELA, 2006, p. 6), "straddling between two cultures", to employ here the meaningful image conceived by Mexican-American scholar Gloria Anzaldúa (1999). Sammar thus keeps connected with the East through Arabic, but uses English to get Rae, her Western receiver, to understand Islam. Later, in the same chapter, Spivak also considers that language is one of the elements which defines cultural identity and describes translation as "one of the ways to get around the confines of one's 'identity" (SPIVAK, 1993, p. 179). Like professor Klondy, Spivak also sees translation as reading and is positive while affirming that "translation is the most intimate act of reading" (SPIVAK, 1993, p. 180) and that she surrenders to the text when she translates. That intimacy between text and translator lies in the act of capturing - by means of interpretation - and redecoding/rewriting the rhetoricity of the language that will be translated, that is, in the understanding of the cultural references and the particular way they are portrayed in the language those cultural manifestations occur. So, for the West to have a clear outline of the East, the differences, the cultural and linguistic limits must be clear. It is then expected from the host culture not only the comprehension of a different cultural realm, but also the respect, the deference to alterity, as Spivak says "absolute alterity or otherness is thus differed-deferred into an other self who resembles us, however minimally, and with whom we can communicate" (SPIVAK, 1993, p. 181). In Aboulela's novel, this deference was 
only possible due to the fact that the recipient of the translated text (Rae) was open to find that resemblance, which enabled the cultural communication between him and Sammar to occur.

In The Translator, Sammar is entitled by the Scottish university as the agent of the process of delimiting - or confining, as Spivak says - the linguistic and cultural boundaries between West and East: she is in charge of redecoding/rewriting meanings which make sense in the latter but, in the former, do not exist and might even embody something strange, culturally out of the way. What is important to note here is that the translator assumed by Spivak in her article has the source language as his or her second language and is supposed to get immersed in it (and in the culture depicted by it as well), in order to make it understood in the target language which is imagined to be his or her own mother tongue. In Aboulela's novel, however, what is portrayed is the contrary situation: Sammar is hired to carry out what in Portuguese is commercially called "versão", that is, the translation of a text produced in the translator's mother tongue into the target language which is expected to be the professional's second language. Then, Sammar's duty is to make comprehensible what for her is something she has known as "true" since birth, something unquestionable, religious and cultural practices and values she must pass on to Rae by means of the indigenous intimacy she has always had with Islam. Although originally born in Scotland, in the city of Aberdeen, Sammar grew up in Sudan and culturally identifies with Islam, her parents' religious belief and homeland respectively. Back to Aberdeen, after her husband Tarig's funeral in Khartoum, she experiences a period of displacement, as she is away from the cultural environment where she grew up and all alone in a place that she feels she does not belong to. In fact, as it was previously said, Scotland is just the physical place where she was born by chance. So, in a strange place and culture, Sammar has her work as a translator as a daily connection with Islam and also sees in Rae, an expert in Eastern studies, an almost perfect counterpart, if it were not for that fact that he is not a Muslim.

American theorist Susan Friedman, in her article entitled "The New Migration: Clashes, Connections, and Diasporic Women's Writing" sees that "Sammar's role as a translator at the University of Aberdeen metaphorizes migration as a form of ongoing cultural translation" (FRIEDMAN, 2009, p. 21). Friedman's argument is based on Sammar's condition as an immigrant, or rather, as a diasporic element, considering here the postcolonial meaning of diaspora, a worldwide voluntary migration caused by economic reasons. Friedman then acknowledges that, in translating, Sammar commutes from East to West, working as a messenger not only taking information from the former to the latter, but also making Islam permanently present in her daily routine in the West. Therefore, along with her clothes, behavior and customs, language must be seen in the novel as one of the most important tokens of her cultural background. In such a diverse cultural ambience, Sammar makes use of translation to build a new meaning of nation and culture. Aboulela's protagonist, then, by means of language/translation, tries to find a new signification to those concepts through a sort of discourse which can face established ideas that have grouped peoples in powerful and powerless. Ellen McCracken, in reference to one argument by Stuart Hall that involves discourse in cultural studies, points out that

[...] much of [the] battle [for power] takes place at the level of discourse. Various groupings, both those with power and those without, attempt to reformulate discursive patterns, rearticulating signifiers in new meaning systems for different political ends than in 
the previous hegemonic instance. A political battle is waged for the power of signification (McCRACKEN, 1999, p. 42).

By translating Arabic into English, and more importantly, by making the Qu'ran understandable to a Western academia, Sammar starts a battle in the discourse arena. Even Rae, a British expert in the Middle East, "author"12 of books among which one that bears the meaningful title The Illusion of an Islamic Threat (ABOULELA, 1999, p. 13), cannot have the same intimacy with Islam as the one Sammar has, for the fact that she has the linguistic knowledge that operates as a key to cultural understanding. Besides, as said before, as a Muslim, she has the inside perspective towards the Islamic cause, something that Rae will acquire only after his religious conversion. From an empiricist angle, the University of Aberdeen comprehends that Sammar has "the authority of experience", as American historian Joan Scott defines it. It was then expected from Aboulela's protagonist a translated narrative from which the Islamic view of the world could not be dissociated, as "experience is [...] a part of everyday language, [deeply] imbricated in [Sammar's translated rewriting]" (SCOTT, 1998, p. 68). In the fictional environment engendered by Leila Aboulela, Sammar's translation work provided the Western Middle East expert with another view of the matter, a view that surpasses the rationality and impartiality of academic knowledge, as he himself declares:

"Ours isn't a religion of suffering", [Rae] said, "nor is it tied to a particular place." His words made her feel close to him, pulled in, closer than any time before because it was "ours" now, not hers alone. And because he understood. Not a religion of pathos, not a religion of redemption and sacrifice. He said "I found out at the end, that it didn't have anything to do with how much I've read or how many facts I've learned about Islam. Knowledge is necessary, that's true. But faith, it comes direct from Allah (ABOULELA, 1999, p. 198).

Also pertinent to the role of translation in Aboulela's novel are the concepts of tradition and translation elaborated by British professor Kevin Robins and discussed by Stuart Hall in his article "The Question of Cultural Identity", included in the collection Modernity: an Introduction to Modern Societies. Tradition then means the attempt to recover the unity of cultural identity lost due to colonialism and this sense of loss is more intense in the globalized world, where different cultures coexist and, in many cases, merge. Therefore, tradition would be understood as an act of resisting assimilation by trying to rescue the cultural oneness, the purity left behind in pre-colonial times. Translation, in its turn, would be the acceptance of diverse cultural influences, the product of which would be then a hybrid culture, a mixture, an intermingling of customs, social and religious practices, ideological positions (HALL, 2007). Analysing the trajectories of Sammar and Rae Isles in The Translator, it seems reasonable to say that Sammar, instead of working as an agent of rescuing what was lost in her cultural past, actually ratifies all the principles embodied by Islam, fundamentals that she knows by heart and strictly follows. In fact, Sammar aims at rescuing what she strongly believes is lost inside Rae, as she senses that he is ready to accept Islam as his religious reference and thus guidance, regarding his understanding, and mainly, his respect for the culture oppressed by his own for centuries. In short, what makes

\footnotetext{
${ }^{12}$ The word author is written between quotation marks, as the book cited is as fictional as Rae Isles, its "writer".
} 
Sammar believe that Rae must convert to Islam is not only his intimacy with her religion and culture but, above all, his deference to difference, to use here Jacques Derrida's terminology, mentioned in Spivak's article already used as a theoretical reference for this paper. Still in this respect, it is interesting to observe what Salman Rushdie in Imaginary Homelands calls "translated men", a concept that is actually a self-reference, since the author is originally from India but grew up in Britain:

The word "translation" comes etymologically from the Latin for "bearing across". Having been borne across the world, we are translated men. It is normally supposed that something gets lost in translation; I cling, obstinately, to the notion that something can also be gained (RUSHDIE, 1992, p. 17).

Based on Rushdie's experience, which is the same as that undergone by many other people migrating from former British colonies, that process of "translation" suffered by Rushdie can be called "westernization", since he left behind or maybe hid among his memories the culture suppressed by the dominant one. Under a postcolonial perspective, however, in Aboulela's novel, the character Rae seems to have taken the contrary course. So, we may argue that Rae undertook a "reverse translation", an "easternization process", since he surrendered, using Spivak's terminology, to a Third World culture, having Sammar as the mediator of this process of assimilation. During the interview to Claire Chambers, while asked why she had chosen to make the protagonist of her first novel work as a translator, Aboulela replied:

I felt that it was important for the theme that Sammar's translating. She's not only translating Arabic into English, she's also translating Islam for Rae - [the two grids Lefevere talks about]. She is the agent for his change. She shows him that Islam is relevant to him too and points out that he needs it. She makes Islam attractive by presenting herself as the prize or reward for his conversion - [the manipulative aspect of Sammar's translating strategy]. Her insistence (which is immature and egoistical) that if Rae loves her he will love Islam has a strong impact on him (Leila Aboulela, IN: CHAMBERS, 2009, p. 95).

Another aspect which also seems to be pertinent here is the cultural environment and the historical moment in which Aboulela's novel develops. Although there is no clear chronological reference, it seems that Sammar and Rae's love story takes place after the Gulf War. The novel was written in 1999, therefore, eight years after the mentioned conflict and, at the very beginning of the novel, there is also a reference to an "anti-terrorist programme" (ABOULELA, 1999, p. 14). So, the translation work Sammar is supposed to do is being developed in recent postcolonial times and, mainly and more meaningfully, after a traumatic moment which had and still has a serious impact all over the world, when the term Muslim is often mistaken for terrorist. Then, considering that she is meant to translate from her mother tongue into English, Sammar, in fact, gives her own interpretation of her own culture, which she learnt through Arabic with her parents, originally Sudanese and Muslims. This is, to some extent, what Klondy calls postcolonial translation, a topic she also approaches in her article previously commented on. According to her text, postcolonial translation is basically characterized by the non-reproduction of the colonizer's discourse and the respect for the culture which is being translated. Again, the assumed translator in Klondy's article is, like that imagined by Gayatry Spivak in her critical work, someone who is translating from a culture which is not his or hers but who 
has deference to difference, using once more Jacques Derrida's words. What happens in The Translator is something particularly different: it is a Muslim woman whose mother tongue is Arabic, a language imbued with rhetoric, who is translating the Qur'an into English, a Western language, which has become - or has been imposed as - the world's lingua franca for economic and political reasons. Thus, Sammar is not only someone who follows those beliefs and religious philosophy, but, more importantly, she is a representative, a spokesperson of Islam and of her own culture. Therefore, Sammar is entitled to decolonize the colonizer's perspective towards the colonized, showing an inner view of a culture which is erroneously associated to negative ideas such as terror, illiteracy, totalitarian regimes and socioeconomic underdevelopment. In her article, Klondy also points out that, along the historical process, colonialism/imperialism and translation worked side by side, when the former used the latter to impose principles and reinforce the colonizer's oppressive discourse over the colonized. Therefore, under a historical perspective, translation has been used as a manipulative device for the oppressor to control the oppressed. In the postcolonial era, however, the same tool which was used by the conqueror to control the conquered is being used by the latter to acquire self-assurance and thus independence. Along with the idea of a manipulative discursive tool, translation was also used by the protagonist to reinforce the concept of nation, certainly affected by the power relations in the postcolonial era - especially while concerning Sammar, a child of diaspora, who has been straddling between two cultures since birth. About this aspect, John Milton declares that "[ $\mathrm{t}]$ ranslation may be important to consolidate the concept of nation, mainly in the case of small and new nations and those which pass by a deep transformation process" (MILTON, 2002, p. 133 - my translation). And this seems to be what happened to Sammar and Rae: she used language, that is, translation, not only to provoke a moment of self-awareness in Rae, or rather, a moment of epiphany in which he recognizes himself in Islam, but also as a stamp of her own national identity. About the role played by translation in the current globalized world, scholars Susan Bassnett and Harish Trivedi managed to sintethize the issue, by stating that

[u]nderstanding the complexities of textual transfer through translation is of especial importance at the present time, for multilingualism, and the cultural interaction it entails, is the norm for millions throughout the world. European languages, once perceived as superior because they were the languages of the colonial masters, now interact with hundreds of languages [and cultures] previously marginalized or ignored outright. Translation has been at the heart of the colonial encounter, and has been used [...] to establish and perpetuate the superiority of some cultures over others. But now, with increasing awareness of the unequal power relations involved in the transfer of texts across cultures, we are in a position to rethink both the history of translation and its contemporary practice (BASSNETT; TRIVEDI, 1998, p. 16-17).

In final considerations, it seems legitimate to affirm that the act of translating, which has Sammar as its performer, is quite meaningful considering the fictional realm engendered by Leila Aboulela: a Western university nominates a Sudanese Muslim woman as its translator for Islamic studies, that is, one of its scholar's understanding of Islam relies on her expertise and experience, which works in the novel as a "revealing agent" of the Islamic cultural identity. Sammar then works as the linking element between Rae and the Eastern environment, when it comes to language and culture. Moreover, she plays a decisive role in all that: she personifies most of what he knows about Islam in the terrain of 
academic studies. On top of that, Sammar functions as the medium of the imposition of the East over the West, or rather, Sammar, as a representative of the Eastern culture, is charging and recovering the respect owed by the West through Rae's conversion to Islam. Then it seems right to say that Sammar's translation work goes beyond phonemes, morphemes, words and sentences. In fact, it surpasses the linguistic arena and stretches out to religion and culture, interpreting Islam by using the English language. And all this is possible only for two basic reasons: on the one hand, there is Sammar who, through her interpretation of the Qu'ran, makes it translatable and comprehensible for Rae; on the other, there is Rae, the receptive recipient of Sammar's translation of Islam. Therefore, Leila Aboulela builds a genuine postcolonial novel, having as its protagonist a woman translator whose expertise is so effective that it worked as a valuable tool to convince a Western scholar to convert into Islam. Although Rae's area of interest is the East, he had always made a point of keeping detached for the sake of his position as a scholar. Thus Sammar, making use of her position as a translator, takes an iconoclastic attitude towards the Western culture, established as a pattern to be followed. Therefore, translation embodies a worthy resource used by Sammar to make the East prevail over the West, to make Islam to be respected, having all that effort occurred, however, in a peaceful and romantic atmosphere.

\section{References}

ABOULELA, Leila. The Translator. Black Cat, New York, 1999.

AGRA, Klondy Lucia de Oliveira. A integração da língua e da cultura no processo da tradução. P. 1-18. Disponível em http://www.bocc.ubi.pt/pag/agra-klondy-integracao-dalingua.pdf. Acesso em junho de 2011.

ANZALDÚA, Gloria. Borderlands the New Mestiza - La Frontera. San Francisco, Aunt Lute Brooks, 1999.

ARROJO, Rosemary. Oficina de tradução. Série Princípios. Ed. Ática. 2003.

BASSNETT, Susan; TRIVEDI, Harish. "Introduction: of colonies, cannibals and vernaculars”. IN: BASSNETT, Susan; TRIVEDI, Harish (org.). Post-colonial Translation: Theory and Practice. London, Routledge, 1999. (p. 1-18).

BASSNETT, Susan. Translation Studies. London, Routledge, 2014.

BENJAMIN, Walter. "The Task of the Translator". IN: VENUTI, Lawrence (ed.) Translation Studies, the Reader. Ed. Lawrence Venuti. London, Roitledge, 2000.

BRAZIEL, Jana E.; MANNUR, Anita. "Nation, Migration: Points of Cntention in Diaspora Studies". IN: BRAZIEL, Jana E.; MANNUR, Anita: Theorizing Diaspora: A Reader. London, Blackwell, 2003. (p. 1-21). 
BRITTO, Paulo Henriques. A tradução literária. Rio de Janeiro, Civilização Brasileira, 2012.

CHAMBERS, Claire. "An Interview with Leila Aboulela". IN: Contemporary Women's Writing. Volume 3. Number 1, 2009. (p. 86-102).

CLIFFORD, James. Routes: Travel and Translation in the Late Twentieth Century. London, Harvard University Press, 1997.

Dicionário eletrônico Houaiss da língua portuguesa 3.0

FRIEDMAN, Susan. “The 'New Migration': Clashes, Connections and Diasporic Women's Writing". IN: Contemporary Women's Writing. Volume 3. Number 1, 2009. (p. 6 - 27).

HALL, Stuart. "The question of cultural identity". IN: HALL, Stuart (org.). Modernity: an Introduction to Modern Societies. Blackwell Publishing, Oxford, 2007. (p. 596 - 633).

. "Thinking the Diaspora: Home-Thoughts from Abroad". Small Axe 6, September 1999. (p. 1-18).

LEFEVERE, André. "Composing the Other". IN: BASSNETT, Susan; TRIVEDI, Harish (org.). Post-colonial Translation: Theory and Practice. London, Routledge, 1998. (p. 7594).

EDUSC, 2007.

. Tradução, reescrita e manipulação da fama literária. Bauru, SP,

Longman Dictionary of Contemporary English. London, Pearson-Longman, 2003.

McCRACKEN. Ellen. New Latina Narrative: The Feminine Space of Postmodern Ethnicity. The University of Arizona Press. Tucson, 1999.

MILTON, John. O Clube do Livro e a tradução. Bauru, SP, EDUSC, 2002.

RÓNAI, Paulo. Escola de tradutores. Rio de Janeiro, José Olympio, 2012.

RUSHDIE, Salman. Imaginary Homelands: Essays and Criticism 1981-1991. London, Penguin Books, 1992. (p. 9-21).

SHOHAT, Ella. Notes on the Post-Colonial. In: Social text. No 31/32, Third World and Post-Colonial Issues, (1992). Available at <http://www.jstor.org/stable/466220. Access: July, 2013. (p. 99-113). Acesso em maio de 2013.

SCOTT, Joan. Experience. In. SMITH, S; WATSON, J. Women, Autobiography, Theory: a Reader. Wisconsin, The University of Wisconsin Press, 1998. (p. 57-71).

Revista Escrita

Rua Marquês de São Vicente, 225 Gávea/RJ CEP 22451-900 Brasil

Ano 2014. Número 19. ISSN 1679-6888.

escrita@puc-rio.br 
SPIVAK, Gayatri. "The Politics of Translation". IN: Outside in the Teaching Machine. New York. Routledge. 1993. (p. 179 - 200).

TYMOCZKO, Maria. Enlarging Western Translation Theory: Integrating Non-Western Thought About Translation. Availabe at www.soas.ac.uk/literatures/satranslations/tymoczko.pdf. Acesso em junho de 2014.

. Postcolonial writing and literary translation. IN: BASSNETT, Susan; TRIVEDI, Harish (org.). Post-colonial Translation: Theory and Practice. London, Routledge, 1998. (p. 19-40).

www.answers.com 